\title{
International News / Nouvelles internationales
}

\section{World Forestry Congress News: Registration forms now available}

Congress registration forms are now available on the Congress Web site. You can register directly online or download the forms in PDF format and fax or mail them back to us. Forms in Word format will also be available soon.

If you have trouble downloading the forms, please contact us right away and we will be happy to fax or mail you them.

Remember that people registering before 1 May 2003 benefit from a significant discount as well as a better choice of hotels.

\section{Official Congress airlines}

Air Canada (www.aircanada.ca) and the Star Alliance Network (www.staralliance.com) have been chosen as the Congress's official airlines and, as such, offer attractive fare discounts to participants. You can take advantage of these by contacting your travel agent, an Air Canada office or a Star Alliance Network company member. To take advantage of the discounts for Congress participants, just mention registration file number CV030221 when you book your flight with Air Canada (from a North American airport) or registration number AC005S3 (if travelling with a Star Alliance member airline from an airport outside North America).

\section{Voluntary papers}

Our appeal for a huge upsurge in the number of quality papers and posters did not go unanswered and has already borne fruit. We are thus pleased to express our sincere gratitude to all those who responded. By early December, we had received more than 900 voluntary papers and posters from over 100 countries a response that was just what we were hoping for!

\section{Speakers}

Good news as well on the guest speaker front. By early December 2002, more than 50 speakers and moderators had notified us of their plans to attend.

\section{Side events}

The list of side events continues to grow and we now have more than 70 . The complete list can be seen on our Web site.

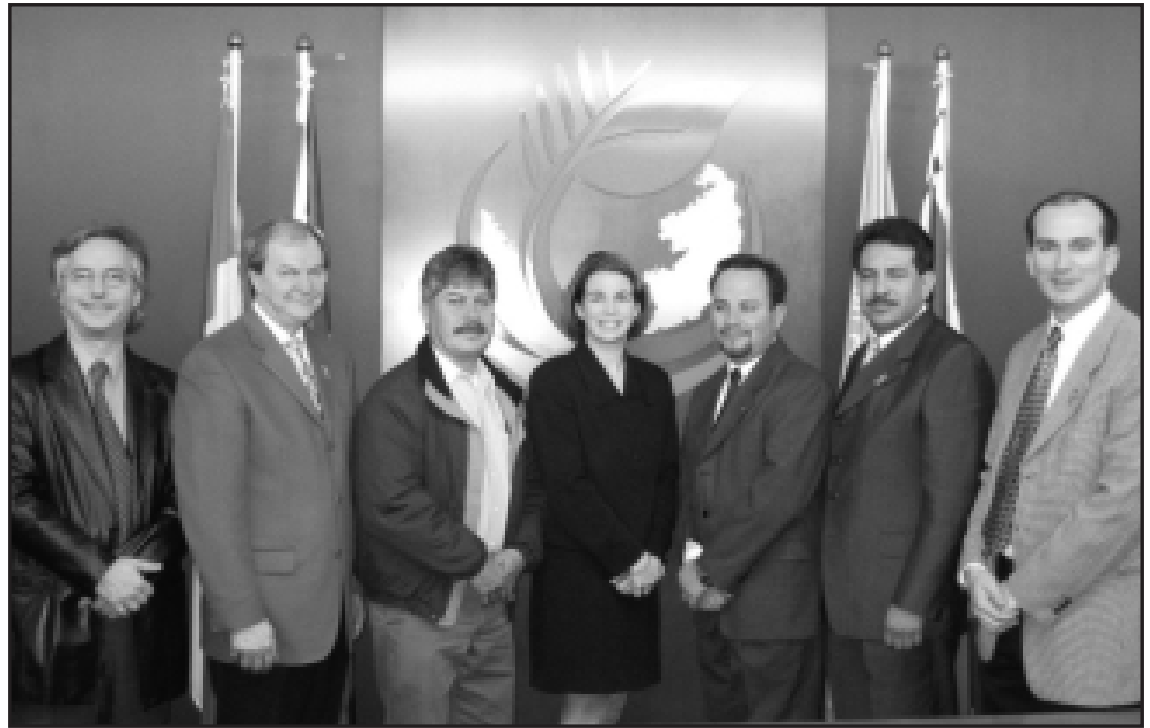

From left to right: Gérard Szaraz, director of Congress operations and programs; JeanLovis Kérovac, Congress secretary-general; Ignacia Marmolejo Altamirano, regional assistant manager, Lerma Santiago-Pacifico; Véronique Perron, international affairs advisor, ministère des Finances, de l'Economie et de la Recherche du Québec; Gustavo Nevárez, director of forest development and head of delegation; José Luis Zuniga, Golf Centre regional manager; and Alberto Sandoval Uribe, CONAFOR's representative in Quebec.

\section{Our Web site proves very popular}

There has been an increasing flow of visitors to our Web site. The November stats show more than 10000 sessions for that month alone, during which 14500 documents were printed out. Approximately $75 \%$ of the site's visitors came from outside Canada.

\section{Visitors from Mexico}

A delegation from the Mexican National Forestry Commission (CONAFOR), accompanied by a Quebec government representative, visited the Congress Secretariat on 19 November.

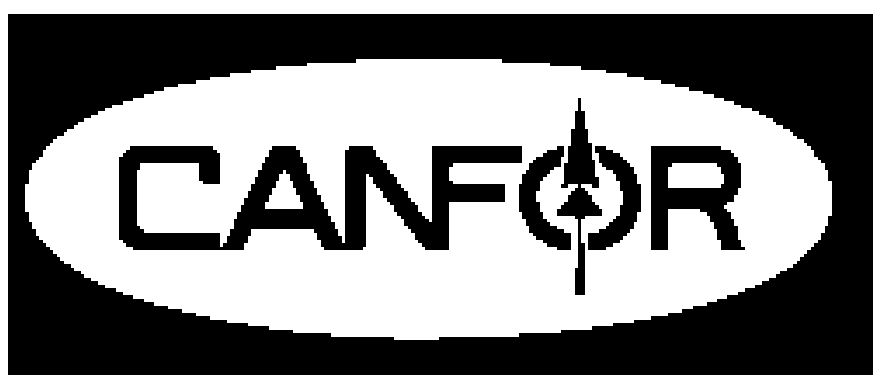

A CIF/IFC Corporate Sustaining Member 


\section{The North American Forestry Commission}

The North American Forest Commission (NAFC) is one of six regional forestry commissions of the Food and Agriculture Organization of the United Nations (FAO). Established in 1958, NAFC provides a policy and technical forum for Canada, Mexico and the United States to discuss and address forest issues on a North American basis.

NAFC carries out its mandate by supporting research and natural resource management activities through seven working groups that explore issues of concern to the three countries. These working groups include: atmospheric change, fire management, forest products, insects and diseases, silviculture, forest inventory and monitoring, and forest genetic resources. Since Canada, Mexico and the United States contain a mix of boreal, temperate and tropical ecosystems, the results of the commission's work can be applied more broadly to assist other countries and regions facing similar conditions.

NAFC countries are represented by the head of their national forest manage- ment agencies. Biennial sessions are held in each country on a rotating basis. Agency heads along with other senior forest officials from the respective countries, non-governmental organizations, FAO and other guests are invited. The week-long sessions address forestry and natural resource matters, advance scientific knowledge in specific topic areas, promote cooperation and facilitate the exchange of information. The most recent commission meeting was hosted by Canada in St. Andrews, New Brunswick, in June of 2000. The next commission meeting will be held in Kona, Hawaii in the United States, in October 2002.

Another feature of the NAFC is the Bureau of Alternates (BOA), which is composed of senior forest service members from Canada, Mexico and the United States. The Bureau of Alternates represent the NAFC Commissioners and meet twice a year to provide guidance on implementing and monitoring the work of the Commission.
Current NAFC commissioners are:

\begin{tabular}{lll} 
Mexico & Canada & USA \\
\hline Raul Enrique Arriaga Becerra & Yvan Hardy & Dale Bosworth \\
Subsecretario de Gestion para la & Assistant Deputy Minister & Chief \\
Proteccion Ambiental & Canadian Forest Service & USDA Forest Service \\
SEMARNAT & Natural Resources Canada & United States Department of \\
Periferico sur 4209 Piso 1 & 580 Booth Street, 8th floor & Agriculture \\
Col. Jardines en la Montana & Ottawa, ON & PO Box 96090 \\
C.P. 14210 & Canada & Washington, DC \\
Ciudad de Mexico & K1A 0E4 & USA \\
Mexico & Tel: 1-613-947-7400 & 20090-6090 \\
Tel: +52-5-628-0623, 0624 & Fax: 1-613-947-7395 & Tel: 1-202-205-1661 \\
Fax: $+52-5-628-0655$ & & Fax: 1-202-205-1765 \\
\hline
\end{tabular}

\section{World Bank Revises Strategy to Foster Conservation Development}

The World Bank's board of directors have approved a new forest strategy to improve the lives of 500 million people living in extreme poverty, while improving the environmental protection of forests, which cover 26 percent of the Earth's land surface and are home to at least 80 percent of remaining terrestrial biodiversity.

Affecting the livelihoods of more than 1.6 billion people in varying degrees, forests help to maintain the fertility of agricultural land, protecting water sources and reducing the risks of natural disasters such as landslides and flooding, the bank said. Yet forests are consistently and seriously undervalued.

The bank's revised forest strategy will work to protect the forests' environmental resources, harness its potential to reduce poverty and create economic opportunities, with special attention directed to the 60 million indigenous peoples who depend on rainforests. The project will also work to bring at least 200 million hectares of production forest, which lie outside strictly protected areas, under sustainable management and put a stop to illegal logging, which currently results in resource losses of up to $\$ 15$ billion every year.

In 2000, the bank's independent Operations Evaluation Department said the bank's 1991 policy had failed to slow deforestation and that destructive and illegal logging practices continued to expand in many developing countries. It recommended the bank modify its strategy, expand its policy to include all forest areas and refocus on poverty reduction and sustainable economic and environmental management, including good governance.
"The old approach of bank disengagement from forestry clearly has not worked," said World Bank President James Wolfensohn. "The new course of action is centered on improving the protection of the environment and biodiversity while increasing the livelihoods of the poor." The new strategy "reflects a vision of responsible growth... The world needs its forests and biodiversity for its very existence and the World Bank is pledged to preserve and defend these essential natural resources" (World Bank release <http://web.worldbank.org).

$$
\begin{aligned}
& \text { W Weyerhaeuser } \\
& \text { The future is growing } \\
& \text { A cIF/IIC Corporate Sustaining Member }
\end{aligned}
$$




\section{The World Bank - A New Forest Policy}

After five years of discussion, the World Bank has finally adopted a new forest policy. Announced last month, the policy replaces the Bank's previous ban on funding logging in primary moist forests. Under the new strategy the Bank will not finance projects that lead to significant loss or degradation of forests in protected areas or that have high conservation value. The new policy also emphasizes forest certification as a tool to achieve sustainable management. The policy does not cover structural adjustment loans. The Bank says a separate policy will address those later.

The World Bank's decision to change its forest policy resulted in part from a review of all the Bank's forest-related work since 1991 by a team led by Uma Lele. As part of the review, the team undertook six studies of how the Bank's activities had affected forests and forestry in Brazil, Cameroon, China, Costa Rica, India, and Indonesia. The Bank published the main review and each of the six studies as separate volumes a couple years ago.

Now, just as the World Bank has approved its new policy, Uma Lele and her colleagues have come out with a new book called "Managing Global Resources: Challenges of Forest Conservation and Development." The book summarizes the six country studies and uses them to draw general conclusions about forests as a global resource.

The authors argue that governments in developing countries with lots of valuable forest such as Brazil, Cameroon, and Indonesia generally want to use their forest to finance economic growth and to provide patronage to their friends. If people in developed countries want these forest-rich developing countries to conserve their forests to provide global benefits such as biodiversity conservation and carbon sequestration they will have to pay them. The real challenge is to figure out how to do that. In contrast, forest-poor countries like China and India now recognize the need to conserve and even restore forests to protect their watersheds and to meet poor people's demands for fuelwood, fodder, and other forest products. These countries have been willing to invest in planting and managing forests provided they could source funds at a reasonable cost.

Like any collection of greatest hits, the book doesn't have a lot that is really new. But it's good to have so much useful information together in one place.

You can purchase the book electronically through Amazon.com and can send comments or questions to Uma Lele at: Ulele@worldbank.org

Dr. David Kaimowitz Director General, CIFOR

\section{Smurfit-Stone and Stora Enso Join NCASI Canada}

The National Council for Air and Stream Improvement (NCASI), Inc. is pleased to announce that Stora Enso North America and Smurfit-Stone Container Corporation have joined NCASI's newly launched Canadian Operations as members as of November 2002. NCASI is a non-profit research organization that provides technical support to the forest products industry on a broad array of environmental issues specific to that industry.

"Joining the National Council will provide a cost-effective resource to support our company's commitment to continuous environmental improvement," stated Tor Suther, Senior Vice President, Uncoated Mechanical Papers for Stora Enso North America. "Maintaining our third-party environmental management certification from the forest through to our end products will be enhanced with the research that NCASI undertakes."

"Smurfit-Stone's US operations have significantly benefited from the work undertaken by NCASI, which has provided rigorous scientific research on environmental challenges we are working to address at both the forest management practices' and mills' levels," commented Alain Dubuc, Vice President, Operations - Eastern Region with Smurfit-Stone
Container Corporation. "Adding this powerful resource to our Canadian operations will give us tools to further improve our environmental performance, thus adding value to our shareholders."

Stora Enso is an integrated forest products company producing magazine papers, newsprint, fine papers, packaging boards and wood products, areas in which the Group is a global market leader. Stora Enso's sales total EUR 13.5 billion and annual paper and board production capacity about 15 million tonnes. Some 43000 persons are employed in more than 40 countries and the Company's shares are listed in Helsinki, New York and Stockholm.

As the largest integrated manufacturer of paperboard- and paper-based packaging, Smurfit-Stone is a leading producer of containerboard, including white top linerboard and recycled medium; corrugated containers; point-of-purchase displays; multiwall and specialty bags; clay-coated recycled boxboard; and is the world's largest paper recycler. In addition, Smurfit-Stone is a leading producer of solid bleached kraft, folding cartons, flexible packaging, and labels. The company operates approximately 300 facilities worldwide and employs approximately 38500 people.
NCASI was established in the United States in 1943 to assist the pulp and paper industry in responding to environmental challenges associated with its manufacturing processes. Over the past six decades, the variety and intensity of environmental issues facing the industry have grown exponentially, and NCASI currently provides technical support across the entire spectrum of these environmental issues. NCASI's reputation as an unbiased source of scientifically credible information has led governments and non-government organizations to rely on its research in providing a rigorous base of knowledge on environmental issues specific to this industry. NCASI has recently opened a base in Montreal, Quebec to directly serve Canadian companies.

For further information, please contact:

Kristen Vice

Vice President, Canadian Operations National Council for Air and Stream Improvement P.O. Box 1490, Station B Montreal, QC H3B $3 \mathrm{~L} 2$ (514) 886-0494 


\section{Asia - The New Frontier}

Mark Twain once responded to an obituary printed in error in a newspaper prior to his death that "news of my death has been greatly exaggerated."

Given the recent marketing successes internationally for Canadian wood products, particularly in Asia, due to the combined efforts of the forest industry, provincial governments and federal governments, the BC forest industry could respond in much the same way.

Canada's patient effort and consistent message regarding the advantages of platform-frame wood construction, especially in areas prone to earthquakes, is beginning to deliver huge dividends in some of the world's most populated emerging markets.

For example, China has agreed in principle to include provisions in its new building codes and standards that fully recognize North American platform-frame wood construction. Because of its established reputation supplying the Asian market, $\mathrm{BC}$ forest companies stand to acquire considerable market share of what is expected to be the largest economy in the world by the middle of this century.

Promoting Canadian wood products abroad has been a group effort involving such organizations as Forintek Canada Corp., Council of Forest Industries (COFI), Forest Renewal BC, the Canada Mortgage and Housing Corporation, Industry Canada, Natural Resources Canada through the Canadian Forest Service and the Department of Foreign Affairs.

As Canada's wood products research institute and with its head office in Vancouver, Forintek has played an important role to ensure that $\mathrm{BC}$ forest products maintain and improve upon their market share in all potential foreign markets. It is a government and industry partnership, with a strong emphasis on applying research results for improving primary and secondary wood product manufacturing, product development and technical support to market opportunities.

"China is the world's largest emerging market for wood products," says Forintek Wood Engineering Department Manager Erol Karacabeyli, "with demand for residential housing estimated at 500 million square metres over the next 20 years."

\section{Wood Products Development}

Faced with such demand, another advantage to platform-frame wood buildings over competing building products is that they are constructed from a renewable resource.

Like other Asian countries certain regions of China are prone to earthquakes. The high performance of platform-frame wood construction in environments such as neighboring Japan has had a positive influence on China's decision to recognize this form of construction in its new building codes.

"Platform-frame wood buildings have been shown to be one of the safest types of structure in earthquakes in North America, New Zealand and Japan," says Karacabeyli. "There is increased interest in this type of construction worldwide, and China is no exception."

Although there is still work to be done on China's fire, seismic and durability performance, quality control and inspection-related codes, the steps taken to open doors in this highly populated country show the type of effort needed to maintain and enhance $\mathrm{BC}$ wood markets.

For example, Canadian and American technical experts were directly involved in the development of Chinese codes and standards for wood-frame construction. That invitation came as a result of trade missions and agreements between North American governments, the Chinese government and industry associations. Forintek has established several agreements with the Chinese Academy of Forestry and several Chinese universities, and its research staff includes several internationally recognized scientists who are graduates from distinguished Chinese universities.

This model of sharing Canadian wood construction techniques, standards and expertise has also proven successful in Japan and Taiwan.

\section{Funding Resources}

Recognizing the importance of striking while the iron is hot, the $\mathrm{BC}$ government has provided funds by earmarking \$146 million for the Forest Investment Account (FIA). A total of $\$ 40$ million of the funding is dedicated to Forestry Innovation Investment programs. Half, or $\$ 20$ million, is designated for research. Another $\$ 12$ million is dedicated to international marketing, specifically to promote the sustainability of $\mathrm{BC}$ forest practices, to support existing markets, and to pursue new market opportunities in China, Southeast Asia and eleswhere. The remaining $\$ 8$ million is designated for new product development, improving manufacturing processes and facilitating timber access for secondary manufactures. Market access initiatives will also be undertaken, including removing technical barriers to trade and ensuring inclusion of $\mathrm{BC}$ products in foreign building codes. These two programs are administered by the Forestry Innovation Investment, which is responsible to a new Forest Investment Council, and will build on a foundation of past industry market development efforts.

"China is the world's largest emerging market for wood products," says Forintek Wood Engineering Department Manager Erol Karacabeyli," with demand for residential housing estimated at 500 million square meters over the next 20 years."

"We're going to be looking at new ideas, new deliverables and new partnerships," says Forest Innovation Investment Executive Director Christine Kennedy.

The administration of the FIA will largely be delivered outside government, through partnership arrangements with the private sector.

In its pursuit of a development strategy for the forest sector. It seems the government understands the concept of taking a focussed and patient approach when attempting to capture significant market share in potentialy lucrative foreign markets.

"It's important to remember that our product development and marketing programs are not just for six weeks or six months," Forests Minister Michael de Jong said when these two programs were announced, "but for years to come. Developing new markets is a lengthy and involved process, and results will take time.'

$\mathrm{BC}$ 's forest industry has a long-standing presence in the Japanese market, built upon that country's traditional use of wood in Japanese-style post-andbeam construction. Based primarily on COFI's efforts, platform-frame hous- 
ing has also been adopted in Japan and has created a market for light framing grades of lumber and wood-based panel products.

As in China, expanding the market for BC wood products in Japan has required patience.

Forintek scientist continue to work very closely with COFI-Japan staff on effective and successful collaborative research projects related to seismic, fire and durability performance of wood products.

Forintek's Markets/Economics Group recently carried out extensive research in Japan on primary and secondary wood products. Attributes demanded by the Japanese people were identified in six product categories, and matched to those that Canadian producers could supply through innovation, and on a competitive and profitable basis.

Over the past six years, Forintek has been working toward having revisions made to Japan's Building Standards Law (BSL), particularly as it relates to highdensity housing. It was revised in 1992 to allow three-story wood-frame buildings in low-density suburban areas and in 1999, it was amended to allow threestorey buildings in high-density urban areas, but in buildings only up to 1500 square metres.

\section{Future Direction}

Forintek will focus its efforts on three areas over the next five years to improve market access to Japan. These are: to undertake research to support revisions to the BSL to permit firewalls between two adjacent three-storey wood-frame buildings in high-density urban areas; provide assistance to Japanese building experts who are processing revisions to the BSL to relax requirements for wood/concrete hybrid structures; and, to use computer models to determine how to construct three-storey woodframe buildings that meet BSL performance-based requirements for high density urban areas.

Progress is steady, but it is always dependent on good research data.

In June of last year, Forintek's research scientists had a rare opportunity to test the performance of buildings in real, controlled fires. The houses were located in Kemano, $\mathrm{BC}$ and were no longer needed by Alcan. The test essentially showed that homes built to Canadian fire code standards prevent the spread of fire and save lives. Those results were shared widely, and Japanese building authorities were among those included.

"Things are moving in Japan," says Forintek Fire Test Project Leader Jim Mehaffey, who recently attended a meeting of the Canada-Japan Housing Committee. Japanese authorities have not yet fully endorsed a performance-based approach to fire-protection design in buildings, but they seem to be moving significantly in that direction.

"We're definitely observing a change in attitudes," adds Mehaffey. "At this point. it's hard to tell how far we can go, but the door is open and it's up to us to jump in with proposals."

Forintek continues to maintain contact with the Taiwan Forestry Research Institute, and is cooperating on forest products-related research at the National Pingtung University as well as the National Taiwan University.

"There's potentially a good and growing market in Taiwan for Canada's wood construction systems and products," says Forintek Western Vice President Jim Dangerfield. "Taiwan already imports a significant amount of wood from Canada, and they are just now becoming very interested in building more platformframe houses because of their superior performance in earthquakes. In turn, they can teach us about value-added manufacturing because of their successful history in that sector."

Taiwan wants to develop a high-quality, sustainable environment, which means substantial lumber imports and more wood-frame houses as compared to alternative building materials. To that end, as with China, Forintek and its Canadian forest industry partners are helping Taiwan revise its building codes to bring about that change.

Taiwan already imports a significant amount of wood from Canada, and they are just now becoming very interested in building more platform-frame houses because of their superior performance in earthquakes.

In addition to homes, Taiwan is also interested in investigating construction of non-residential structures with dimensional lumber.

Use of wood in non-residential applications is one area where there is definite room for improvement, starting in BC's own backyard. About 50 percent of nonresidential construction taking place in North America could use wood. Also, the total value of non-residential construction rivals that of residential construction.

What is concerning, according to Forintek Markets/ Economics group

\begin{tabular}{|c|c|c|}
\hline 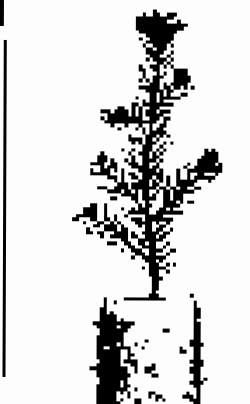 & 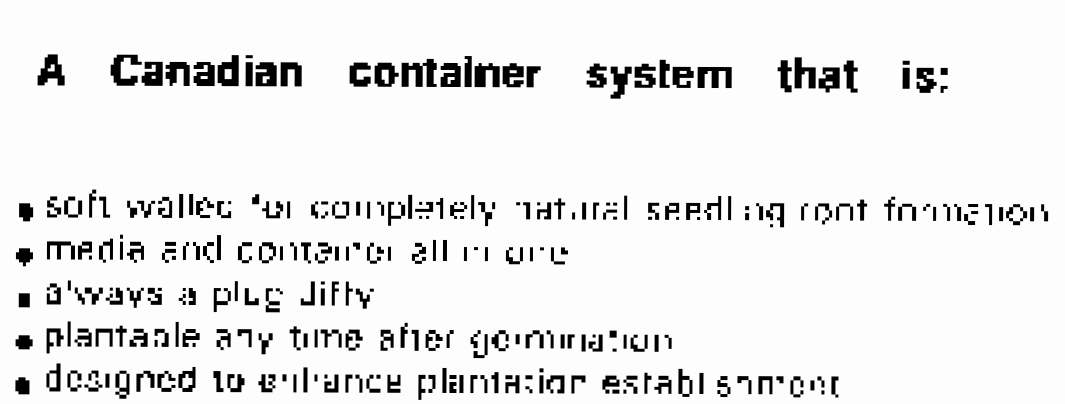 & $\begin{array}{c}\text { Gruw sula } \\
\text { with } \\
\text { withits }\end{array}$ \\
\hline 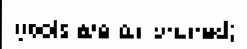 & & \\
\hline
\end{tabular}


leader Chris Gaston, is that a recent survey of American respondents showed that use of wood as a structural component in non-residential construction has declined and that the environmentally friendly perception of wood is also on the wane. The three top negative attributes ascribed to wood were code limitations, poor performance and poor durability.

\section{Buildings Construction Market}

"Code, performance, product, attitudinal and promotional issues all need to be addressed if wood is to be used more often in business and public buildings," says Gaston, "But the potential rewards are considerable."

Based on the unbiased factual data that are now available concerning the response of wood-frame construction in earthquake zones, this presents a marketing opportunity for BC wood products into other prone areas outside of the Pacific Rim.

According to Forintek's Karacabeyli, there is growing evidence that many countries are seriously considering building with wood rather than concrete, especially where there is concern about earthquakes. For example, Forintek knows of one major Canadian lumber manufacturer that is selling wood into Turkey through an American exporter. Furthermore, a multinational truss maker with outlets in Calgary and Turkey is building a plant in Turkey's capital of Ankara.

"It doesn't necessarily mean that we will sell more wood products to these countries," says Karacabeyli, "but it makes the pie bigger for everyone and perhaps takes the competitive pressure off some of our more traditional foreign markets."

Successful market penetration extends beyond marketing. It also means pro- viding the market with the right product or a superior product.

For its part, Forintek is actively engaged in the research and development of a number of innovative building systems. For example, it has trademarked its MIDPLYTM system and is currently testing it with a Vancouver builder. The system provides builders with a short shear wall option, and it is easy to make. It uses 2by-3 studs turned sideways and nailed against each other on either side of a central sheathing panel. Furthermore, it is specially designed to resist lateral forces from earthquake and wind.

"The MIDPLYTM system has proven itself in lab tests," says Building Industry Advisor with Forintek's Western Division, Jennifer O'Connor. "It was used in a four-storey condominium recently constructed in Vancouver by Polygon Homes, one of BC's largest builders of mutli- and single-family wood-frame homes."

Typically, builders use other materials for shear-resistant walls. By using 2by-3s, the product also offers a welcome market for sawmills faced with smaller diameter logs and high production of 2by-3s.

Change in market demand for wood products is inevitable. Companies that recognize the changing winds of market demand and invest in product development to fit those markets stand to benefit significantly. Given recent marketing accomplishments, $\mathrm{BC}$ is poised to diversify beyond traditional markets.

Source: Trucklogger

\section{Stora Enso strengthens research co-operation in China}

Stora Enso has signed a comprehensive framework agreement for co-operation in research and development with the Chinese Academy of Forestry in Beijing. The agreement, signed on November 27, 2002, establishes the basis for a wide range of studies in the field of reforestation and use of plantation wood for papermaking, including the use of native poplar trees. This agreement enhances the ongoing joint research work on developing fast-growing southern, mainly eucalyptus, species for efficient use in pulp and paper manufacture.
For further information, please contact:

Tim Laatsch, Senior Vice President, Communications, Stora Enso North America, tel. 7154224023

Scott Deitz, Vice President, Investor

Relations, Stora Enso North America, tel. 7154221521 www.storaenso.com, www.storaenso.com/investors

\section{One}

Billion

Trees

and

counting

We thank our customers, employees, investors and suppliers for making this milestone possible.

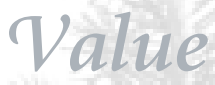

\section{\\ Forest Seedlings}

$\triangle$ Seed

\A Cold Storage

¿ Seed Orchard Management

\\ Native Plants

¿ Reforestation Services*

* available at PRT Frontier in Dryden, Ontario

\section{Reliability}

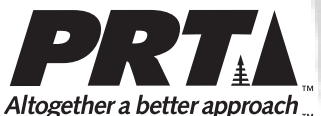

PRT Corporate Office \#4 - 1028 Fort Street Victoria, BC V8V $3 \mathrm{~K} 4$ $250381-1404$ TEL $250381-0252$ FAX prt@prtgroup.com EMAIL 


\section{Healthy Forests}

\section{An Initiative for Wildfire Prevention and Stronger Communities in the United States}

The American people, their property, and our environment, particularly the forests and rangelands of the West, are threatened by catastrophic fires and environmental degradation. Hundreds of millions of trees and invaluable habitat are destroyed each year by these severe wildfires. These unnaturally extreme fires are caused by a crisis of deteriorating forest and rangeland health, the result of a century of well-intentioned but misguided land management. Renewed efforts to restore our public lands to healthy conditions are needed.

\section{This fire season is already one} of the worst in modern history - Already more than 5.9 million acres of public and private land have burned this year, an area the size of New Hampshire and more than twice the average annual acreage, with more than a month of fire season remaining. Fires have burned 500000 acres more than they had at this time during the record-setting 2000 fire season.

- Hundreds of communities have been affected by these wildfires. Tens of thousands of people have been evacuated from their homes, and thousands of structures have been destroyed. With more people living near forests and rangelands, it is becoming increasingly difficult to protect people and their homes. Land managers must do more to address the underlying causes of these fires.

\section{Catastrophic fires are caused by deteriorating forest and rangeland health}

America's public lands have undergone radical changes during the past century due to the suppression of fires and a lack of active forest and rangeland management. Frequent, low-intensity fires play an important role in healthy forest and rangeland ecosystems, maintaining natural plant conditions and reducing the buildup of fuels. Natural, low-intensity fires burn smaller trees and undergrowth while leaving large trees generally intact. Natural fires also maintain natural plant succession cycles, preventing the spread of invasive plant species in forests and rangelands. This produces forests that are open and resistant to disease, drought, and severe wildfires.
Today, the forests and rangelands of the West have become unnaturally dense, and ecosystem health has suffered significantly. When coupled with seasonal droughts, these unhealthy forests, overloaded with fuels, are vulnerable to unnaturally severe wildfires. Currently, 190 million acres of public land are at increased risk of catastrophic wildfires.

\section{These deteriorated forest and rangeland conditions significantly affect people, property, and ecosystem health}

- Fuels have accumulated so significantly that fires no longer burn at natural temperatures or rates, making them dangerous to fight and difficult to control. Catastrophic wildfires grow extremely quickly, making them difficult to control if they are not stopped immediately. For example, the Rodeo fire in Arizona grew from 800 acres to 46000 acres in just one day.

- Nearly 83 percent of firefighters surveyed identified the need for fuels reduction as the top priority for improving their safety.

- Catastrophic wildfires burn at much higher temperatures than normal fires, causing long-lasting and severe environmental damage. A large, catastrophic fire can release the energy equivalent of an atomic bomb. Rather than renewing forests, these fires destroy them. While most natural fires burn at ground level and at relatively low temperatures, these catastrophic fires burn at extreme temperatures, destroying entire forests and sterilizing soils. These extreme fires can even kill giant sequoia trees that have survived centuries of natural fires. It can take as long as a century for forests to recover from such severe fires.

\section{Enhanced measures are needed to restore forest and rangeland health to reduce the risk of these catastrophic wildfires}

Federal, state, tribal and local governments are making unprecedented efforts to reduce the buildup of fuels and restore forests and rangelands to healthy conditions. Yet, needless red tape and lawsuits delay effective implementation of forest health projects. This year's crisis compels more timely decisions, greater efficiency, and better results to reduce catastrophic wildfire threats to communities and the environment.

The Healthy Forests Initiative will implement core components of the National Fire Plan's 10-year Comprehensive Strategy and Implementation Plan. This historic plan, which was adopted this spring by federal agencies and western governors, in collaboration with county commissioners, state foresters, and tribal officials, calls for more active forest and rangeland management. It establishes a framework for protecting communities and the environment through local collaboration on thinning, planned burns and forest restoration projects.

Source: US Forest Service, (see www.fs.fed.us for the full report)

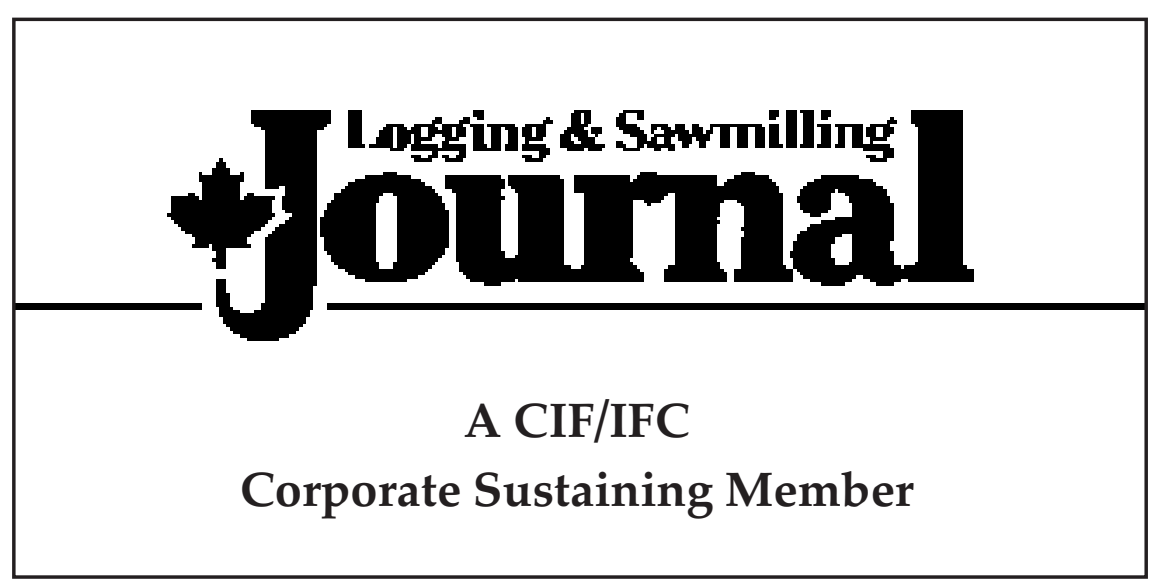




\section{Illegal logging in Indonesia}

"Illegal activities are one of the most pressing problems facing the Indonesian forest sector," says Luca Tacconi from CIFOR. "They reduce government revenues, cheat local communities of income, foster a vicious cycle of bad governance and destroy the forest."

Estimates of the extent of illegal logging highlight the enormity of the problem. Between 55 and $75 \%$ of industrial wood production is thought to be illegal, resulting in a loss of anywhere between US\$1 billion and US\$ 1.9 billion in tax revenue. Official imports of timber into Sabah in Malaysia are about ten percent of estimated actual total imports.

CIFOR and Indonesia's Forest Research and Development Agency (FORDA), in partnership with Pionir Bulungan in East Kalimantan and the Centre for Social and Economic Research on the Global Environment, have been researching illegal forest activities with funding from DfID.

It is clear illegal logging continues unabated despite official statements about the will to address the situation, hence the need to research to understand the complex driving forces, the stakeholders involved and their interests, and ways to intervene.

Recent policy changes legalizing smallscale logging in production forests have not had the desired effect of reducing ille- gal logging. In many cases these activities are not controlled by local communities, but by commercial interests that continue to carry out illegal activities.

"Illegal logging provides incomes to people with few other alternatives," says CIFOR consultant Krystof Obidzinski. "Since manual small-scale extraction by rural people is probably one of the leastdestructive forms of illegal logging, an argument could be made for legalizing such activities and in the process co-opting rural people as forest guardians."

However, recent experience from Indonesia shows that changes in the regulatory framework to allow small-scale extraction by rural people were manipulated to divert rents to the rich and powerful, leaving the local communities with a lower share of timber value.

A ban on exports of logs was introduced in October 2001. But recent fieldwork in Kalimantan and Malaysia shows it has not been effective in reducing illegal harvest and exports.

"Economic forces are a fundamental driver of illegal forest activities," says Tacconi, "The incentives and disincentives, including the cost of being caught and being prosecuted, faced both by illegal and legal operators, need to be researched to understand how policies could be used to make the legal market more attractive than the illegal one."

\section{Carbon markets for the poor}

October 2002 marks the beginning of a new round of international climate change negotiations - the Eighth Session of the Conference of the Parties in New Delhi. During the last round in Marrakesh negotiators decided that countries could meet part of their commitments to reduce carbon emissions for 2008-2012 by financing afforestation and reforestation in developing countries. That is supposed to happen through the Kyoto Protocol's Clean Development Mechanism (CDM). After 2012 other types of forestry activities such as conservation and reduced impact logging might also qualify as CDM projects.

"Forest Carbon and Local Livelihoods" by Joyotee Smith from CIFOR and Sara Scherr from Forest Trends looks at what this might mean for the rural poor. It examines the livelihood benefits and risks associated with large- scale forest plantations, small woodlots, agroforestry, forest regeneration, natural forest managed by communities, and strict protection. Each option poses benefits and risks, but in general the smaller-scale more community-based options offer greater benefits for rural livelihoods.

The authors show that small-scale forestry CDM projects are likely to have greater environmental benefits and less risk of "leakage" (i.e., encouraging carbon emissions outside project boundaries) than large-scale plantation projects. Small farmer and community CDM forestry projects appear viable from an economic perspective but they are likely to be more expensive than large-scale projects. That is because of the high cost of organizing and monitoring large numbers of small farmers and the lower productivity of their forestry activ-
Law enforcement in itself is not sufficient to address the problem. Where corruption is endemic, major improvements in surveillance, such as remote sensing, log tracking, and monitoring by third parties, are likely to be more effective than increasing penalties. This could also reduce corruption because bribes need to be higher and may fail more often.

Weak governance and political patronage play a role in illegal logging and foster a cycle of corruption whereby rich individuals can acquire and hold on to powerful positions by carrying out illegal activities.

The range of actors involved in illegal activities complicates the situation. These include large concession companies, small logging operators, large and small sawmills, rural people, central and district government officers, politicians, and government officers in other countries, as well as foreign companies.

"Unless the potential rewards from illegal activities for the various actors are reduced, it is unlikely that the complex chain of illegal activities that links the various actors from the forest to the national and international markets will be broken," concludes Tacconi.

Source: CIFOR News

ities. It means that if governments want small producers to benefit from the CDM they will have to take steps to ensure they can compete effectively with the larger players.

Specifically, the authors say the CDM project guidelines should require social impact assessments and consultations with local stakeholders to make sure that the CDM projects don't make local people lose access to their forests or their land. The CDM guidelines need to make sure small farmer plantations, agroforestry, and forest regeneration activities qualify for support. Small-scale projects have to have simple reporting requirements. National governments can do their part be educating local people about the CDM, helping them to develop CDM projects and by making sure that they have secure ownership rights over their trees and forests. 


\section{Organization for UNFF Third Session Begins}

The third UNFF Session will take place in Geneva, Switzerland 26 May - 3 June 2003. In order to ensure timely preparation and organization of these events, information such as registration for delegations, intergovernmental organizations and major groups, travel support, side event registraton and Multistakeholder Dialoge (MSD) organization are now posted on the UNFF website (http://www.un.org/esa/forests/session.html). The UNFF Secretariat encourages all who wish to participate to review the information available. If planning on attending UNFF3, please ensure that the necessary endorsements for attendance as part of their offical delegation are obtained from your respective Permanent Mission to the United Nations, IGO or accredited NGO in order to ensure timely processing of information.

For further information contact: sarmac@un.org

Source: Newsletter, United Nations Forum on Forests (UNFF)

\section{World's Oldest Tree to be Cloned}

Inyo National Forest, CA - The US Forest Service (USFS) and the Champion Tree Project are attempting to clone the world's oldest tree, a 4767-year-old bristlecone pine. For eons the bristlecones have flourished atop the arid mountains of the Great Basin, from Colorado to California, enduring extreme hardships and adjusting to their environment. The Director of Cooperative Forestry at USFS, Larry Payne, says that they support the concept of studying the oldest and largest trees in order to learn more about their genetics and the factors that have allowed them to live for so long.

\section{Carbon markets}

As its name implies, the Clean Development Mechanism is supposed to promote development as well as help avoid climate change. This report shows how that can happen.

An electronic copy in word or pdf format is available at: NSabarniati@cgiar.org

Dr. David Kaimowitz Director General, CIFOR

\section{Shared Responsibilities are Key to Containing US Wildfire Costs}

A National Academy of Public Administration Panel has found that federal, state, and local agencies must strike at the main causes of wildland fires in order to bring the costs of fighting them under control. These costs have increased dramatically with the buildup of hazardous fuels feeding the fires, rising home construction in fire-prone areas, and severe drought.

In a report released today, the Panel focussed on federal wildfire assistance to state and local governments and the need to better prepare federal, state, local, and tribal officials to work together. A key element would be a federal incentive program aimed at reducing hazardous fuels, improving fire prevention, and managing fires more cost effectively. The Panel found these incentives necessary to get everyone working together more effectively. And the costs need to be shared among those who benefit.

The Panel found few easy answers or short-term solutions. "Fire suppression is more than a one-year, single-incident proposition," said Phoenix, Arizona City Manager Frank Fairbanks, who chaired the Panel. "It requires long-term foresight and striking at the root causes of these growing hazards. Unless the amount of hazardous fuels can be reduced and communities made fire-resistant, wildfires will continue to grow larger, more intense and damaging, and even more costly to fight."

Federal budget-makers have become increasingly aware of the growing demand for federal funds to respond to wildfire hazards. They doubled the funds for this purpose as a result of the severe wildfires in 2000, but were still told that this was just a down payment. Concerned that this program might become a bottomless pit, Congress called for the Academy study. Meanwhile, the cost of these fires is estimated to exceed $\$ 1.5$ billion in 2002, not including the loss of life, homes, and property.

Studies of six large fires from 2001 formed the basis for the Panel's findings and recommendations. Each fire illustrated a different story about firefighting strategies, tactics, and costs.

The Green Knoll Fire, in Jackson Hole, Wyoming, vividly demonstrated how home construction in forests influences firefighting strategies and increases costs. It also showed the value of federal, state, and local cooperation. The fire burned almost 4500 acres and cost $\$ 13.3$ million. But, no lives were lost and property damage was limited.

The Sheep Fire, in northern Nevada, burned nearly 84000 mostly rangeland acres and cost $\$ 2.2$ million. Few structures were threatened, but area ranchers were highly concerned about the loss of grazing lands and future incomes. This concern significantly affected the firefighting strategy and increased costs.

The Virginia Lake Fire, in eastern Washington, started when a lightning storm ignited 18 fires almost simultaneously on the Colville Indian Reservation. It burned 74000 acres and cost $\$ 25.2$ million. The fire spread rapidly due to weather conditions and the lack of readily available firefighting resources. Many of the resources had already been assigned to other serious fires. This case demonstrated problems that can arise when coordinating efforts of local firefighters with federal fire management officials.

The Arthur Fire in Yellowstone National Park burned 2800 acres at an estimated cost of $\$ 6.3$ million. This fire in Wyoming showed how terrain adversely affects firefighting tactics. It also demonstrated how having well-trained local personnel can improve overall fire management and reduce suppression costs.

The Star Fire, which began in the Eldorado National Forest east of Sacramento, California, was the most expensive - \$28.2 million - of the cases studied. Much of the cost resulted from a policy requirement that human-cased fires be quickly suppressed and from the extensive use of aircraft. The demand to protect a naturally treasured grove of Sequoia trees also played a significant role.

The Moose Fire near Kalispell, Montana raised issues about wildfires that cross jurisdictions. The fire spread over lands managed by two federal agencies (the Forest Service and National Park Service), a state forest, and private lands protected by Flathead County. These entities took different approaches that resulted in contention over responsibility for some costs.

Source: National Academy of Public Administration 